\title{
PENGARUH MEDIA AUDIOVISUAL TERHADAP KEMAMPUAN BERARGUMENTASI MAHASISWA PROGRAM STUDI SASTRA CHINA DALAM MATA KULIAH “CHINA TODAY”
}

\author{
Yuk Ting \\ Universitas Kristen Maranatha \\ lin.yt@lang.maranatha.edu
}

\begin{abstract}
ABSTRAK
Pencapaian keterampilan berkomunikasi secara lisan akan sangat terlihat melalui keterampilan berbicara. Dan seberapa baik keterampilan berbicara sangat berkaitan dengan kemahiran dalam menangkap dan mencerna informasi melalui proses mendengar (Huiyuan, 2005). Dalam pembelajaran bahasa Mandarin di tingkat mahir, semakin luas wawasan pengetahuan yang dimiliki para peserta didik akan sangat memperkaya kemampuan di dalam berbicara. Mata kuliah "China Today" merupakan mata kuliah menyimak pada tingkat mahir, dimana mahasiswa harus memberikan tanggapan secara lisan atas tayangan diskusi yang ditayangkan melalui media audiovisual. Berdasarkan pengamatan di lapangan, ditemukan ada dua cara yang secara konsisten digunakan oleh mahasiswa dalam memaparkan argumentasi, yaitu pertama adalah penyampaian ulasan singkat dengan cara mengulangi kembali beberapa kalimat yang terdapat di dalam tayangan audiovisual. Yang kedua adalah penyampaian ulasan secara menyeluruh (mencakup aspek-aspek yang disebutkan di dalam materi audiovisual), kemudian dilanjutkan dengan argumentasi pribadi. Jika dilihat berdasarkan proses menyimak sebagaimana yang dijelaskan oleh Tarigan, maka seharusnya mahasiswa akan menggunakan cara kedua. Melalui penelitian ini diharapkan dapat mengidentifikasi kata-kata apa saja yang diambil dari tayangan audiovisual, yang kemudian digunakan oleh mahasiswa dalam memaparkan argumentasi. Penelitian ini juga akan menganalisa pengaruh dari media audiovisual terhadap kemampuan mahasiswa dalam menyampaikan argumentasi dalam bahasa Mandarin.
\end{abstract}

Kata kunci: argumentatif; audiovisual; bahasa Mandarin; media

\begin{abstract}
The achievement of the level of language skills in learning Mandarin at the tertiary level is largely determined by the level of depth of knowledge received by students. The subject "China Today" is a listening course at the advanced level, where students must respond to Mandarin language discussions in the audiovisual media. Based on the field observations, it was found that there were two ways that are consistently used among students in presenting their arguments. The first is the delivery of short reviews and arguments that just repeat a few sentences according to what are they heard in the audiovisual media. The second is the submission of a complete review (covering all aspects mentioned in the audiovisual media), then followed by personal arguments. In the final listening process, as described by Tarigan, students should use the second way to present their arguments, to prove that they had achieved to the advanced level. The aim of this research is to identify which vocabulary was taken from audiovisual media, to analyze the effect of audiovisual media on students' ability in presenting arguments in the Mandarin language.
\end{abstract}

Keywords: argumentative; audiovisual; Mandarin language; media

\section{PENDAHULUAN}

Ilmu bahasa mengenal dua keterampilan lisan, yaitu keterampilan menyimak dan berbicara. Keterampilan menyimak merupakan tahap pertama dalam mempelajari suatu bahasa, yang juga berfungsi untuk menghantarkan pembelajar bahasa kepada kemampuan berbicara (Hesheng, 2006). Oleh karena itu 
perlu pertimbangan yang sangat cermat dalam pemilihan materi pembelajaran.

Tarigan menuliskan ada lima tahapan dalam proses menyimak, dimulai dari tahap menyimak segala sesuatu yang dikemukakan oleh pembicara, sampai dengan tahap memberikan tanggapan atas seluruh informasi yang diterima (Tarigan, 2008). Penelitian ini dilakukan di dalam mata kuliah "China Today" yang merupakan mata kuliah menyimak tingkat mahir. Penyampaian materi diberikan langsung di tempat, tidak disediakan daftar kata-kata baru. Meski demikian mahasiswa tetap diarahkan melalui pertanyaan-pertanyaan penuntun agar mereka dapat merespon sesuai dengan tema diskusi yang diangkat di dalam media audiovisual. Berdasarkan observasi di lapangan, ada dua cara yang digunakan oleh mahasiswa dalam memberikan respon, yaitu:

1. Menyampaikan ulasan singkat dengan hanya mengulang (meniru) beberapa kalimat yang didengarkan melalui tayangan audiovisual.

2. Menyampaikan ulasan secara lengkap (mencakup seluruh aspek yang disebutkan di dalam materi audiovisual), kemudian dilanjutkan dengan memberikan argumentasi pribadi.

Jika dilihat dari proses menyimak sebagaimana yang dijelaskan oleh Tarigan, maka seharusnya di dalam pemaparan argumentasi seluruh mahasiswa pada akhirnya harus dapat menggunakan cara kedua dalam proses berargumentasi.

Penelitian ini ditujukan untuk mengidentifikasi kelas kata dari kata-kata yang digunakan oleh mahasiswa dalam memaparkan argumentasi. Selain itu penelitian ini juga hendak menganalisa bagaimana pengaruh dari tayangan audiovisual terhadap kemampuan mahasiswa untuk berargumentasi dalam Bahasa Mandarin.

\section{METODE}

Penelitian ini merupakan penelitian kualitatif deskriptif, yakni memaparkan data- data faktual yang diperoleh dari observasi di lapangan, kemudian membandingkannya dengan materi sumber (Thoir \& Danawaty, 1984). Dalam penelitian ini diambil dari media audiovisual.

Pengumpulan data penelitian dilakukan dengan cara memberikan pertanyaan penuntun untuk membantu para responden (yang adalah mahasiswa peserta kelas China Today) dalam memberikan respon berupa argumentasi terhadap isi materi audiovisual. Seluruh respon lisan direkam secara bersamaan. Hasil rekaman suara ini kemudian dibuat menjadi transkripsi untuk memudahkan proses klasifikasi dan analisis data. Langkah terakhir adalah membuat simpulan penelitian.

\section{PEMBAHASAN}

Judul Materi Audiovisual:

两岸谈中华文化 (Liang'an tan Zhonghua Wenhua)

Pada materi audiovisual ini ada 4 (empat) orang narasumber, yaitu 于丹 (Yu Dan) Profesor dari Beijing Normal University, 黄光 男 (Huang Guangnan) - Rektor dari Taiwan Art University, 田青 (Tian Qing) - Intangible Cultural Heritage Protection Center, dan 林谷 芳 (Lin Gufang) - Pusat Riset Fo Guang Art University. Keempat narasumber tersebut adalah ahli budaya di China daratan (RRT) dan Taiwan. Keempatnya memaparkan argumentasi tentang penilaian terhadap perkembangan dan pergeseran nilai-nilai budaya yang terjadi di antara dua tepian dari kedua negara tersebut.

Dan berikut ini adalah rekapitulasi daftar kosakata yang digunakan dalam pemaparan argumentasi yang disampaikan oleh keempat narasumber tersebut, yang terdiri dari nomina, verba, ajektiva, pronomina, adverbia, preposisi dan konjungsi (Jianxiong, 2008; Kridalaksana, 2005). 
PENGARUH MEDIA AUDIOVISUAL TERHADAP KEMAMPUAN BERARGUMENTASI ...

Tabel 1. Rekapitulasi Daftar Kata dari Tayangan Audiovisual

\begin{tabular}{|c|c|c|c|c|c|c|}
\hline Preposisi & Nomina & Pronomina & Adverbia & Verba & Konjungsi & Ajektiva \\
\hline 在 & 台湾 & 你 & 其实 & 感觉 & 跟 & 一样 \\
\hline 在...中 & 中国大陆 & 大家 & 应该 & 说 & 因为...,所以... & 谦和 \\
\hline 在...上 & 文化 & 每 & 完全 & 有 & 因为 & 和谐 \\
\hline 除了 & 差异 & 自己 & 都 & 交流 & 和 & 清楚 \\
\hline \multirow[t]{43}{*}{ 从 } & 人 & 我们 & 非常 & 会 & 比如说 & 明显 \\
\hline & 方式 & 我 & 在一起 & 想 & 连...都... & 好 \\
\hline & 孔子 & 这样 & 整个 & 用 & ...的时候 & 细小 \\
\hline & 话 & 他们 & 几乎 & 讲 & 即使 & 深 \\
\hline & 个性 & 每 & 本来 & 可以 & 比如 & 友善 \\
\hline & 背景 & 这 & 所有的 & 成长 & 但 & 陌生 \\
\hline & 过程 & 它 & 比较 & 觉得 & 或者 & 大 \\
\hline & 两岸 & 这些 & 很 & 包括 & 以...为... & 早 \\
\hline & 古代 & 她 & 才 & 开玩笑 & & 整个 \\
\hline & 书 & 那么 & 就 & 相信 & & 次要 \\
\hline & 民间 & 老一代 & 尤其是 & 过去 & & 安然 \\
\hline & 生活 & 这 & 非常 & 保持 & & 消极 \\
\hline & 整体 & 怎么 & 让 & 能 & & \\
\hline & 中华 & 自己 & 刚才 & 变成 & & \\
\hline & 关系 & 这样 & 很 & 可以 & & \\
\hline & 信仰 & 某些 & 很多 & 看到 & & \\
\hline & 神 & 这 & 可能 & 渗透 & & \\
\hline & 鬼 & 它 & 常常 & 实践 & & \\
\hline & 民俗 & & 有时间 & 补充 & & \\
\hline & 传说 & & 干脆 & 讲 & & \\
\hline & 节庆 & & 比较 & 受到 & & \\
\hline & (两) 点 & & 就 & 影响 & & \\
\hline & 感受 & & 根本 & 识字 & & \\
\hline & 礼仪 & & 认为 & 具有 & & \\
\hline & 教育 & & ...以来 & 发展 & & \\
\hline & 行为 & & 一直 & 出来 & & \\
\hline & 邦 & & 即使 & 问路 & & \\
\hline & 校长 & & 整个 & 带 & & \\
\hline & 戏曲 & & 还是 & 晓得 & & \\
\hline & 内容 & & 难道 & 接受 & & \\
\hline & 道家 & & 稳定 & 是...的 & & \\
\hline & 佛家 & & 尤其是 & 发现 & & \\
\hline & 影响 & & 更 & 不能 & & \\
\hline & 现在 & & 真实 & 写 & & \\
\hline & 标杆 & & & 编 & & \\
\hline & 意义 & & & 出版 & & \\
\hline & 茶艺 & & & 不知道 & & \\
\hline & 台北 & & & 急迫 & & \\
\hline & 街头 & & & 发扬 & & \\
\hline & 陌生人 & & & 忽略 & & \\
\hline & 朋友 & & & 意识 & & \\
\hline & 情感 & & & 边陲化 & & \\
\hline & 教育 & & & 起来 & & \\
\hline
\end{tabular}


PENGARUH MEDIA AUDIOVISUAL TERHADAP KEMAMPUAN BERARGUMENTASI ...

\begin{tabular}{cl}
\hline 基础 & 发展 \\
\hline 早期 & 放 \\
\hline 个人 & 怀古 \\
\hline 感觉 & 帮助 \\
\hline 作家 & 谈 \\
\hline 艺术 & 濒临 \\
\hline 老师 & 消失 \\
\hline 盗版 & 抢救 \\
\hline 名字 & 反应 \\
\hline 问题 & \\
\hline 价值 & \\
\hline 氛围 & \\
\hline 场域 \\
\hline 形态 \\
\hline 位置 \\
\hline 现人 \\
\hline 当代 \\
\hline 社会 \\
\hline 尊严 \\
\hline 课题 \\
\hline 正面 \\
\hline 文明 \\
\hline 需要 \\
\hline
\end{tabular}

Dapat dilihat pada tabel 1 bahwa keempat narasumber menggunakan kata-kata yang terdiri dari preposisi, pronomina, nomina, adverbia, verba, konjungsi, ajektiva, dan peribahasa. Ditemukan keseragaman pemilihan kata-kata (lihat yang diberi cetak tebal), yaitu:

- Pronomina: 每, 这样, 这, 它。

- Adverbia: 很, 很多, 比较, 就, 认为, 尤其是。

- Verba: 是...的, 不能, 发展。

Kata-kata yang sama yang digunakan oleh para narasumber tersebut merupakan katakata yang diperkenalkan pada tingkat pemula dan tingkat terampil dalam pembelajaran bahasa Mandarin, yang juga berfungsi sebagai penyusun di dalam struktur kalimat.

Tabel 1 tidak memperlihatkan adanya kesamaan pemakaian kata-kata pada kelompok preposisi, nomina, konjungsi, ajektiva. Ini merupakan indikasi berargumen yang sehat, karena konten argumen dari para narasumber tidak saling tumpang tindih, sehingga seluruh argumen dapat semakin memperkaya wawasan berpikir sesuai dengan tema yang diangkat.

\section{Identifikasi Kata-kata yang Digunakan dari Audiovisual}

Data pada tabel 1 selanjutnya dianalisis dengan cara kroscek pemakaian kata-kata berdasarkan klasifikasi kelas kata yang digunakan dalam argumentasi dari setiap responden. Urutan klasifikasi dimulai dari preposisi, nomina, pronomina, adverbia, verba, konjungsi, ajektiva. Jumlah responden di sini ada 13 (tiga belas) orang, yang seluruhnya merupakan mahasiswa yang menempuh mata kuliah China Today. 
Tabel 2. Daftar Preposisi yang Digunakan oleh Responden 1-13.

\begin{tabular}{|c|c|c|c|c|c|c|c|c|c|c|c|c|c|c|c|}
\hline \multicolumn{3}{|c|}{ Kata-kata yang digunakan } & \multirow{2}{*}{$\frac{R l}{\mathbf{x}}$} & \multirow{2}{*}{$\begin{array}{c}R 2 \\
\mathbf{x}\end{array}$} & \multirow{2}{*}{$\begin{array}{c}R 3 \\
\mathbf{x}\end{array}$} & \multirow{2}{*}{$\begin{array}{c}R 4 \\
\mathbf{x}\end{array}$} & \multirow{2}{*}{$\begin{array}{c}R 5 \\
\mathbf{x}\end{array}$} & \multirow{2}{*}{$\begin{array}{c}R 6 \\
\mathbf{x}\end{array}$} & \multirow{2}{*}{$\begin{array}{c}R 7 \\
\mathbf{x}\end{array}$} & \multirow{2}{*}{$\begin{array}{c}R 8 \\
\checkmark\end{array}$} & \multirow{2}{*}{$\begin{array}{c}R 9 \\
\mathbf{x}\end{array}$} & \multirow{2}{*}{$\frac{R 10}{\mathbf{x}}$} & \multirow{2}{*}{$\frac{R 11}{\mathbf{x}}$} & \multirow{2}{*}{$\begin{array}{c}R 12 \\
\checkmark\end{array}$} & \multirow{2}{*}{$\frac{R 13}{\mathbf{x}}$} \\
\hline 1. & 在 & zai & & & & & & & & & & & & & \\
\hline 2. & 从 & cong & $\checkmark$ & $x$ & $\checkmark$ & $x$ & $\checkmark$ & $\checkmark$ & $\checkmark$ & $x$ & $\checkmark$ & $\checkmark$ & $\checkmark$ & $x$ & $\checkmark$ \\
\hline
\end{tabular}

$\underline{\text { Keterangan: }}$ tanda $(\checkmark)$ berarti ditemukan pemakaian kata pada responden tersebut.

Analisis tabel 2: Kelompok Preposisi.

Pada tabel 1 diketahui ada 5 (lima) preposisi yang digunakan oleh para narasumber, dan di tabel 2 dapat dilihat bahwa responden telah memilih menggunakan dua buah preposisi, yaitu preposisi 在 (zai) yang dalam bahasa Indonesia dipadankan dengan kata depan "di-", yang digunakan oleh responden ke-9 dan 13; dan 从 (cong) yang dalam bahasa Indonesia dipadankan dengan kata depan "dari", yang digunakan oleh responden $1,3,5,6,7,8,10,11$ dan 12.

Tabel 3. Daftar Nomina yang Digunakan oleh Responden 1-13

\begin{tabular}{|c|c|c|c|c|c|c|c|c|c|c|c|c|c|c|c|}
\hline \multicolumn{3}{|c|}{ Kata-kata yang digunakan } & $R l$ & $R 2$ & $R 3$ & $R 4$ & $R 5$ & R6 & $R 7$ & $R 8$ & $R 9$ & R10 & R11 & R12 & $R 13$ \\
\hline 1. & 台湾 & Taiwan & $\checkmark$ & $x$ & $x$ & $x$ & $x$ & $\checkmark$ & $\checkmark$ & $\checkmark$ & $x$ & $x$ & $x$ & $\checkmark$ & $x$ \\
\hline 2. & $\begin{array}{l}\text { 中国 } \\
\text { (大陆) }\end{array}$ & $\begin{array}{l}\text { Zhongguo } \\
\text { (dalu) }\end{array}$ & $\checkmark$ & $x$ & $x$ & $x$ & $\checkmark$ & $\checkmark$ & $\checkmark$ & $\checkmark$ & $x$ & $x$ & $x$ & $\checkmark$ & $\checkmark$ \\
\hline 3. & 文化 & wenhua & $\checkmark$ & $\checkmark$ & $\checkmark$ & $\checkmark$ & $\checkmark$ & $\checkmark$ & $\checkmark$ & $\checkmark$ & $\checkmark$ & $\checkmark$ & $\checkmark$ & $\checkmark$ & $\checkmark$ \\
\hline 4. & 人 & ren & $x$ & $\checkmark$ & $x$ & $x$ & $\checkmark$ & $x$ & $x$ & $x$ & $x$ & $x$ & $x$ & $x$ & $x$ \\
\hline 5. & 两岸 & liang'an & $x$ & $x$ & $x$ & $x$ & $x$ & $x$ & $\checkmark$ & $x$ & $x$ & $x$ & $x$ & $x$ & $x$ \\
\hline 6. & 古代 & gudai & $\checkmark$ & $x$ & $x$ & $x$ & $x$ & $x$ & $x$ & $\checkmark$ & $x$ & $x$ & $x$ & $x$ & $x$ \\
\hline 7. & 书 & shu & $\checkmark$ & $x$ & $x$ & $x$ & $x$ & $x$ & $x$ & $\checkmark$ & $x$ & $x$ & $x$ & $x$ & $x$ \\
\hline 8. & 生活 & shenghuo & $x$ & $x$ & $x$ & $x$ & $x$ & $x$ & $\checkmark$ & $x$ & $x$ & $x$ & $x$ & $x$ & $x$ \\
\hline 9. & 整体 & zhengti & $\checkmark$ & $x$ & $x$ & $x$ & $x$ & $x$ & $x$ & $x$ & $x$ & $x$ & $x$ & $x$ & $x$ \\
\hline 10. & 神 & shen & $x$ & $x$ & $x$ & $x$ & $x$ & $\checkmark$ & $x$ & $x$ & $x$ & $x$ & $x$ & $x$ & $x$ \\
\hline 11. & 鬼 & gui & $x$ & $x$ & $x$ & $x$ & $x$ & $\checkmark$ & $x$ & $x$ & $x$ & $x$ & $x$ & $x$ & $x$ \\
\hline 12. & 点 & dian & $x$ & $x$ & $x$ & $x$ & $x$ & $x$ & $\checkmark$ & $x$ & $x$ & $x$ & $x$ & $x$ & $x$ \\
\hline 13. & 感受 & ganshou & $x$ & $x$ & $x$ & $x$ & $x$ & $x$ & $x$ & $x$ & $x$ & $x$ & $x$ & $x$ & $x$ \\
\hline 14. & 礼仪 & liyi & $x$ & $x$ & $x$ & $x$ & $\checkmark$ & $x$ & $x$ & $x$ & $x$ & $x$ & $\checkmark$ & $x$ & $x$ \\
\hline 15. & 现在 & xianzai & $x$ & $x$ & $x$ & $\checkmark$ & $x$ & $x$ & $x$ & $x$ & $x$ & $x$ & $x$ & $x$ & $x$ \\
\hline 16. & 价值 & jiazhi & $x$ & $x$ & $x$ & $x$ & $\checkmark$ & $x$ & $\checkmark$ & $x$ & $\checkmark$ & $x$ & $x$ & $\checkmark$ & $x$ \\
\hline 17. & 社会 & shehui & $x$ & $x$ & $x$ & $x$ & $x$ & $x$ & $x$ & $x$ & $x$ & $x$ & $\checkmark$ & $x$ & $x$ \\
\hline
\end{tabular}

$\underline{\text { Keterangan: }}$ tanda $(\checkmark)$ berarti ditemukan pemakaian kata pada responden tersebut.

\section{Analisis tabel 3: Kelompok Nomina.}

Dari tabel 1 diketahui ada 70 (tujuh puluh) nomina yang digunakan oleh para narasumber, dan di tabel 3 ini dapat dilihat bahwa responden telah memilih menggunakan nomina-nomina berikut ini:

- Nomina 台湾 (Taiwan) yang artinya "negara Taiwan", digunakan oleh responden 1,6,7,8 dan 12;

- Nomina 中国 (Zhongguo) yang artinya "negara China (RRT)", digunakan oleh responden 1,5,6,7,8,12 dan 13;

- Nomina 文化 (wenhua) yang artinya "budaya", digunakan oleh responden 1 sampai dengan 13;
- Nomina 人 (ren) yang artinya "orang", digunakan oleh responden 2 dan 5;

- Nomina 古代 (gudai) yang artinya "era kuno", digunakan oleh responden 1 dan 8;

- Nomina 书 (shu) yang artinya "buku", digunakan oleh responden 1 dan 8;

- Nomina 整 体 (zhengti) yang artinya "keseluruhan", digunakan oleh responden 1;

- Nomina 神 (shen) yang artinya "Tuhan/dewa", digunakan oleh responden 6 ;

- Nomina 鬼 (gui) yang artinya "setan", digunakan oleh responden 6;

- Nomina 礼 仪 (liyi) yang artinya "ritual/upacara", digunakan oleh responden 5 dan 11; 
- dan 价值 (jiazhi) yang artinya "nilai", digunakan oleh responden 5,7,9 dan 12;

- Nomina 影响 (yingxiang) yang artinya "pengaruh", digunakan oleh responden 6;

- Nomina 现 在 (xianzai) yang artinya "sekarang" digunakan oleh responden 4.

- Nomina 两岸 (liang'an) yang artinya “dua tepian", digunakan oleh responden 7 ;

- Nomina 生活 (shenghuo) yang artinya "hidup", digunakan oleh responden 7;
- Nomina 点 (dian) yang artinya "poin", digunakan oleh responden 7 ;

- Nomina 现代人 (xiandairen) yang artinya "orang masa kini", digunakan oleh responden 11.

Tabel 4. Daftar Pronomina yang Digunakan oleh Responden 1-13.

\begin{tabular}{l|lllllllllllllll}
\hline \multicolumn{2}{c}{ Kata-kata yang digunakan } & $R 1$ & $R 2$ & $R 3$ & $R 4$ & $R 5$ & $R 6$ & $R 7$ & $R 8$ & $R 9$ & $R 10$ & $R 11$ & $R 12$ & $R 13$ \\
\hline 1. & 你 & ni & $\mathbf{x}$ & $\mathbf{x}$ & $\mathbf{x}$ & $\mathbf{x}$ & $\mathbf{x}$ & $\mathbf{x}$ & $\mathbf{x}$ & $\mathbf{x}$ & $\mathbf{x}$ & $\mathbf{x}$ & $\mathbf{x}$ & $\mathbf{x}$ & $\checkmark$ \\
2. & 每 & mei & $\checkmark$ & $\mathbf{x}$ & $\checkmark$ & $\mathbf{x}$ & $\checkmark$ & $\mathbf{x}$ & $\checkmark$ & $\mathbf{x}$ & $\checkmark$ & $\mathbf{x}$ & $\mathbf{x}$ & $\mathbf{x}$ & $\mathbf{x}$ \\
3. & 自己 & ziji & $\mathbf{x}$ & $\checkmark$ & $\checkmark$ & $\checkmark$ & $\checkmark$ & $\checkmark$ & $\checkmark$ & $\checkmark$ & $\checkmark$ & $\mathbf{x}$ & $\checkmark$ & $\mathbf{x}$ & $\checkmark$ \\
4. & 我们 & women & $\checkmark$ & $\checkmark$ & $\checkmark$ & $\checkmark$ & $\checkmark$ & $\mathbf{x}$ & $\mathbf{x}$ & $\checkmark$ & $\checkmark$ & $\checkmark$ & $\mathbf{x}$ & $\checkmark$ & $\checkmark$ \\
5. & 我 & wo & $\mathbf{x}$ & $\mathbf{x}$ & $\mathbf{x}$ & $\mathbf{x}$ & $\mathbf{x}$ & $\checkmark$ & $\mathbf{x}$ & $\mathbf{x}$ & $\mathbf{x}$ & $\mathbf{x}$ & $\mathbf{x}$ & $\mathbf{x}$ & $\checkmark$ \\
6. & 这样 & zheyang & $\mathbf{x}$ & $\mathbf{x}$ & $\checkmark$ & $\mathbf{x}$ & $\mathbf{x}$ & $\mathbf{x}$ & $\mathbf{x}$ & $\mathbf{x}$ & $\mathbf{x}$ & $\checkmark$ & $\mathbf{x}$ & $\mathbf{x}$ & $\mathbf{x}$ \\
7. & 他们 & tamen & $\mathbf{x}$ & $\checkmark$ & $\mathbf{x}$ & $\checkmark$ & $\mathbf{x}$ & $\mathbf{x}$ & $\mathbf{x}$ & $\checkmark$ & $\checkmark$ & $\mathbf{x}$ & $\mathbf{x}$ & $\checkmark$ & $\mathbf{x}$ \\
8. & 这 & zhe & $\mathbf{x}$ & $\mathbf{x}$ & $\mathbf{x}$ & $\mathbf{x}$ & $\mathbf{x}$ & $\checkmark$ & $\mathbf{x}$ & $\checkmark$ & $\mathbf{x}$ & $\mathbf{x}$ & $\mathbf{x}$ & $\mathbf{x}$ & $\mathbf{x}$ \\
9. & 这些 & zhexie & $\mathbf{x}$ & $\mathbf{x}$ & $\mathbf{x}$ & $\mathbf{x}$ & $\mathbf{x}$ & $\mathbf{x}$ & $\mathbf{x}$ & $\mathbf{x}$ & $\mathbf{x}$ & $\mathbf{x}$ & $\checkmark$ & $\mathbf{x}$ & $\mathbf{x}$ \\
10. & 她 & ta & $\mathbf{x}$ & $\mathbf{x}$ & $\mathbf{x}$ & $\mathbf{x}$ & $\mathbf{x}$ & $\mathbf{x}$ & $\mathbf{x}$ & $\mathbf{x}$ & $\mathbf{x}$ & $\mathbf{x}$ & $\checkmark$ & $\mathbf{x}$ & $\mathbf{x}$ \\
11. & 那么 & name & $\checkmark$ & $\mathbf{x}$ & $\mathbf{x}$ & $\mathbf{x}$ & $\mathbf{x}$ & $\mathbf{x}$ & $\mathbf{x}$ & $\mathbf{x}$ & $\mathbf{x}$ & $\checkmark$ & $\mathbf{x}$ & $\mathbf{x}$ & $\mathbf{x}$
\end{tabular}

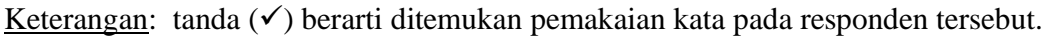

\section{Analisis tabel 4: Kelompok Pronomina.}

Pada tabel 1 diketahui ada 16 (enam belas) buah pronomina yang digunakan oleh para narasumber, dan di tabel 4 ini dapat dilihat bahwa responden telah menggunakan pronomina berikut ini:

- Pronomina 你 (ni) yang artinya "kamu", digunakan oleh responden 13;

- Pronomina 每 (mei) yang artinya "tiap/setiap", digunakan oleh responden 1,3,5,7 dan 9;

- Pronomina 自己 (ziji) yang artinya "diri sendiri", digunakan oleh responden 2,3,4,5,6,7,8,9,11 dan 13;

- Pronomina 我们 (women) yang artinya "kami/kita", digunakan oleh responden $1,2,3,4,5,8,9,10,12$ dan 13 ;
- Pronomina 我 (wo) yang artinya "saya", digunakan oleh responden 6 dan 10;

- Pronomina 这样 (zheyang) "yang artinya begini", digunakan oleh responden 3,8,9 dan 12;

- Pronomina 他们 (tamen) yang artinya "mereka", digunakan oleh responden 2,4 dan 8;

- Pronomina 这 (zhe) yang artinya "ini”" (tunggal), digunakan oleh responden 6;

- Pronomina 这些 (zhexie) yang artinya “ini” (jamak), digunakan oleh responden 11;

- Pronomina 那么 (name) yang artinya “jika demikian", digunakan oleh responden 1.

- Pronomina 她(ta) yang artinya "dia” (untuk perempuan", digunakan oleh responden 10. 
Tabel 5. Daftar Adverbia yang Digunakan oleh Responden 1-13.

\begin{tabular}{l|lllllllllllllll}
\hline \multicolumn{2}{c}{ Kata-kata yang digunakan } & $R 1$ & $R 2$ & $R 3$ & $R 4$ & $R 5$ & $R 6$ & $R 7$ & $R 8$ & $R 9$ & $R 10$ & $R 11$ & $R 12$ & $R 13$ \\
\hline 1. & 其实 & qishi & $\mathbf{x}$ & $\mathbf{x}$ & $\mathbf{x}$ & $\mathbf{x}$ & $\mathbf{x}$ & $\mathbf{x}$ & $\checkmark$ & $\mathbf{x}$ & $\mathbf{x}$ & $\mathbf{x}$ & $\mathbf{x}$ & $\mathbf{x}$ & $\mathbf{x}$ \\
2. & 完全 & wanquan & $\mathbf{x}$ & $\mathbf{x}$ & $\mathbf{x}$ & $\mathbf{x}$ & $\mathbf{x}$ & $\mathbf{x}$ & $\mathbf{x}$ & $\checkmark$ & $\mathbf{x}$ & $\mathbf{x}$ & $\mathbf{x}$ & $\mathbf{x}$ & $\mathbf{x}$ \\
3. & 都 & dou & $\mathbf{x}$ & $\mathbf{x}$ & $\checkmark$ & $\mathbf{x}$ & $\checkmark$ & $\checkmark$ & $\checkmark$ & $\mathbf{x}$ & $\mathbf{x}$ & $\mathbf{x}$ & $\mathbf{x}$ & $\checkmark$ & $\mathbf{x}$ \\
4. & 在一起 & zaiyiqi & $\checkmark$ & $\mathbf{x}$ & $\mathbf{x}$ & $\mathbf{x}$ & $\mathbf{x}$ & $\mathbf{x}$ & $\mathbf{x}$ & $\mathbf{x}$ & $\mathbf{x}$ & $\mathbf{x}$ & $\mathbf{x}$ & $\mathbf{x}$ & $\mathbf{x}$ \\
5. & 很 & hen & $\checkmark$ & $\checkmark$ & $\mathbf{x}$ & $\checkmark$ & $\checkmark$ & $\checkmark$ & $\mathbf{x}$ & $\mathbf{x}$ & $\checkmark$ & $\checkmark$ & $\checkmark$ & $\mathbf{x}$ & $\checkmark$ \\
6. & 尤其是 & youqi shi & $\mathbf{x}$ & $\mathbf{x}$ & $\mathbf{x}$ & $\mathbf{x}$ & $\checkmark$ & $\mathbf{x}$ & $\mathbf{x}$ & $\mathbf{x}$ & $\mathbf{x}$ & $\mathbf{x}$ & $\mathbf{x}$ & $\mathbf{x}$ & $\mathbf{x}$ \\
7. & 更 & geng & $\mathbf{x}$ & $\mathbf{x}$ & $\mathbf{x}$ & $\checkmark$ & $\mathbf{x}$ & $\mathbf{x}$ & $\mathbf{x}$ & $\mathbf{x}$ & $\checkmark$ & $\mathbf{x}$ & $\mathbf{x}$ & $\checkmark$ & $\checkmark$
\end{tabular}

$\underline{\text { Keterangan: }}$ tanda $(\checkmark)$ berarti ditemukan pemakaian kata pada responden tersebut.

Analisis tabel 5: Kelompok Adverbia.

Pada tabel 1 diketahui ada 31 (tiga puluh satu) buah adverbia, dan di tabel 5 dapat dilihat beberapa kata berikut ini telah dipilih dan digunakan oleh para responden, yaitu:

- Adverbia 完全 (wanquan) yang berarti "sepenuhnya", digunakan oleh responden 1 dan 8;

- Adverbia 都 (dou) yang berarti "seluruhnya", digunakan oleh responden $3,5,6,7$ dan 12 ;
- Adverbia 在一起 (zaiyiqi) yang berarti "bersama-sama", digunakan oleh responden 1;

- Adverbia 很 (hen) yang berarti "sangat", digunakan oleh responden $1,2,4,5,6,9,10,11$ dan 13 ;

- Adverbia 尤其是(youqi shi) yang berarti "khususnya", digunakan oleh responden 5;

- Adverbia 其实 (qishi) yang berarti "sesungguhnya", digunakan oleh responden 7;

- Adverbia 更(geng) yang berarti "lebih", digunakan oleh responden 4,9,12 dan 13.

Tabel 6. Daftar Verba yang Digunakan oleh Responden 1-13.

\begin{tabular}{|c|c|c|c|c|c|c|c|c|c|c|c|c|c|c|c|}
\hline \multicolumn{3}{|c|}{ Kata-kata yang digunakan } & \multirow{2}{*}{$\begin{array}{c}R 1 \\
\checkmark\end{array}$} & \multirow{2}{*}{$\begin{array}{c}R 2 \\
\mathbf{x}\end{array}$} & \multirow{2}{*}{$\begin{array}{c}R 3 \\
\mathbf{x}\end{array}$} & \multirow{2}{*}{$\begin{array}{c}R 4 \\
\times\end{array}$} & \multirow{2}{*}{$\begin{array}{c}R 5 \\
\mathbf{x}\end{array}$} & \multirow{2}{*}{$\begin{array}{c}R 6 \\
\times\end{array}$} & \multirow{2}{*}{$\begin{array}{l}R 7 \\
\mathbf{x}\end{array}$} & \multirow{2}{*}{$\begin{array}{c}R 8 \\
\mathbf{x}\end{array}$} & \multirow{2}{*}{$\begin{array}{c}R 9 \\
\mathbf{x}\end{array}$} & \multirow{2}{*}{$\frac{R 10}{\mathbf{x}}$} & \multirow{2}{*}{$\frac{R 11}{\mathbf{x}}$} & \multirow{2}{*}{$\frac{R 12}{\mathbf{x}}$} & \multirow{2}{*}{$\frac{R 13}{\mathbf{x}}$} \\
\hline 1. & 感觉 & ganjue & & & & & & & & & & & & & \\
\hline 2. & 说 & shuo & $x$ & $\checkmark$ & $x$ & $x$ & $\checkmark$ & $x$ & $x$ & $x$ & $x$ & $\checkmark$ & $x$ & $x$ & $x$ \\
\hline 3. & 有 & you & $\checkmark$ & $x$ & $\checkmark$ & $x$ & $\checkmark$ & $x$ & $x$ & $x$ & $\checkmark$ & $\checkmark$ & $\checkmark$ & $\checkmark$ & $\checkmark$ \\
\hline 4. & 会 & hui & $\checkmark$ & $\checkmark$ & $x$ & $x$ & $x$ & $x$ & $\checkmark$ & $x$ & $x$ & $x$ & $x$ & $x$ & $x$ \\
\hline 5. & 想 & xiang & $x$ & $x$ & $x$ & $x$ & $x$ & $x$ & $x$ & $x$ & $x$ & $x$ & $x$ & $x$ & $\checkmark$ \\
\hline 6. & 用 & yong & $x$ & $\checkmark$ & $x$ & $x$ & $x$ & $x$ & $x$ & $x$ & $x$ & $x$ & $x$ & $x$ & $x$ \\
\hline 7. & 包括 & baokuo & $x$ & $x$ & $x$ & $x$ & $x$ & $x$ & $x$ & $\checkmark$ & $x$ & $x$ & $x$ & $x$ & $x$ \\
\hline 8. & 保持 & baochi & $x$ & $\checkmark$ & $x$ & $x$ & $x$ & $\checkmark$ & $x$ & $x$ & $\checkmark$ & $\checkmark$ & $x$ & $\checkmark$ & $x$ \\
\hline 9. & 能 & neng & $x$ & $x$ & $x$ & $x$ & $x$ & $x$ & $x$ & $x$ & $\checkmark$ & $x$ & $\checkmark$ & $\checkmark$ & $x$ \\
\hline 10. & 可以 & keyi & $x$ & $x$ & $x$ & $x$ & $x$ & $x$ & $x$ & $x$ & $\checkmark$ & $x$ & $x$ & $x$ & $x$ \\
\hline 11. & 看到 & kan dao & $x$ & $x$ & $\checkmark$ & $x$ & $x$ & $x$ & $\checkmark$ & $x$ & $x$ & $x$ & $x$ & $\checkmark$ & $\checkmark$ \\
\hline 12. & 影响 & yingxiang & $x$ & $x$ & $x$ & $x$ & $x$ & $x$ & $x$ & $\checkmark$ & $\checkmark$ & $x$ & $x$ & $x$ & $x$ \\
\hline 13. & 具有 & juyou & $x$ & $\checkmark$ & $x$ & $x$ & $x$ & $x$ & $x$ & $x$ & $x$ & $x$ & $x$ & $x$ & $x$ \\
\hline 14. & 带 & dai & $x$ & $x$ & $x$ & $x$ & $x$ & $x$ & $x$ & $x$ & $\checkmark$ & $x$ & $x$ & $x$ & $x$ \\
\hline 15. & (不) 知道 & (bu) zhidao & $x$ & $\checkmark$ & $x$ & $x$ & $x$ & $x$ & $x$ & $\checkmark$ & $x$ & $x$ & $x$ & $\checkmark$ & $x$ \\
\hline 16. & 发扬 & fayang & $x$ & $x$ & $x$ & $x$ & $x$ & $\checkmark$ & $x$ & $x$ & $x$ & $x$ & $x$ & $x$ & $x$ \\
\hline 17. & 忽略 & hulue & $x$ & $x$ & $x$ & $x$ & $\checkmark$ & $\checkmark$ & $x$ & $x$ & $x$ & $x$ & $x$ & $x$ & $x$ \\
\hline 18. & 边陲化 & bianchuihua & $x$ & $x$ & $\checkmark$ & $x$ & $x$ & $\checkmark$ & $\checkmark$ & $x$ & $x$ & $x$ & $x$ & $\checkmark$ & $x$ \\
\hline 19. & 消失 & xiaoshi & $x$ & $x$ & $x$ & $x$ & $x$ & $x$ & $x$ & $x$ & $\checkmark$ & $x$ & $x$ & $x$ & $x$ \\
\hline
\end{tabular}

$\underline{\text { Keterangan: }}$ tanda $(\checkmark)$ berarti ditemukan pemakaian kata pada responden tersebut. 
Analisis tabel 6: Kelompok Verba.

Pada tabel 1 diketahui ada 52 (lima puluh dua) buah verba yang digunakan oleh para rasumber, dan pada tabel 6 dapat dilihat beberapa kata berikut telah dipilih dan digunakan oleh para responden:

- Verba 感觉 (ganjue) yang berarti “merasa", digunakan oleh responden 1 ;

- Verba 说 (shuo) yang berarti "berkata", digunakan oleh responden 2,5 dan 10 ;

- Verba 有 (you) yang berarti "mempunyai", digunakan oleh responden 1,3,5,9,10,11,12 dan 13;

- Verba 会 (hui) yang berarti "dapat/bisa", digunakan oleh responden 1,2 dan 7;

- Verba 想 (xiang) yang berarti “ingin”, digunakan oleh responden 13;

- Verba 用 (yong) yang berarti "menggunakan", digunakan oleh responden 2;

- Verba 包括 (baokuo) yang berarti "mencakup", digunakan oleh responden 8;

- Verba 保持 (baochi) yang berarti “menjaga (tetap dalam suatu keadaan)", digunakan oleh responden 2,6,9,10 dan 12;

- Verba 能 (neng) yang berarti "mampu/dapat", digunakan oleh responden 9,11 dan 12;
- Verba 可以 (keyi) yang berarti "boleh", digunakan oleh responden 9;

- Verba 看到 (kan dao) yang berarti “dapat dilihat", digunakan oleh responden 3,7,12 dan 13;

- Verba 影响 (yingxiang) yang berarti "mempengaruhi", digunakan oleh responden 8 dan 9;

- Verba 具有 (jüyou) yang berarti "memiliki", digunakan oleh responden 2;

- Verba 带 (dai) yang berarti "membawa", digunakan oleh responden 9;

- Verba (不) 知道 (buzhidao) yang berarti "tidak tahu", digunakan oleh responden 2,8 dan 12;

- Verba 消失 (xiaoshi) yang berarti "lenyap", digunakan oleh responden 9.

- Verba 发扬 (fayang) yang berarti "mengembangkan", digunakan oleh responden 6;

- Verba 忽 略 (hulue) yang berarti "mengabaikan", digunakan oleh responden 5 dan 6;

- Verba 边陲化 (bianchuihua) yang berarti "memarjinalkan", digunakan oleh responden 3,6,7 dan 12 .

Tabel 7. Daftar Konjungsi yang Digunakan oleh Responden 1-13.

\begin{tabular}{|c|c|c|c|c|c|c|c|c|c|c|c|c|c|c|c|}
\hline \multicolumn{3}{|c|}{ Kata-kata yang digunakan } & $R 1$ & $R 2$ & $R 3$ & $R 4$ & $R 5$ & $R 6$ & $R 7$ & $R 8$ & $R 9$ & $R 10$ & $R I 1$ & $R 12$ & $R 13$ \\
\hline 1. & 跟 & gen & $x$ & $x$ & $x$ & $x$ & $x$ & $x$ & $x$ & $x$ & $x$ & $x$ & $\checkmark$ & $x$ & $x$ \\
\hline 2. & 因为 & yinwei & $x$ & $x$ & $x$ & $\checkmark$ & $x$ & $\checkmark$ & $x$ & $x$ & $\checkmark$ & $x$ & $x$ & $x$ & $\checkmark$ \\
\hline 3. & 和 & he & $x$ & $\checkmark$ & $x$ & $x$ & $x$ & $x$ & $x$ & $x$ & $x$ & $x$ & $x$ & $x$ & $x$ \\
\hline 4. & 比如说 & birushuo & $x$ & $x$ & $\checkmark$ & $x$ & $x$ & $\checkmark$ & $x$ & $x$ & $x$ & $x$ & $x$ & $\checkmark$ & $x$ \\
\hline 5. & 连...都... & lian..., dou... & $x$ & $x$ & $x$ & $x$ & $x$ & $\checkmark$ & $x$ & $x$ & $x$ & $x$ & $x$ & $x$ & $x$ \\
\hline 6. & ...的时候 & ...de shihou & $x$ & $x$ & $\checkmark$ & $x$ & $x$ & $x$ & $x$ & $\checkmark$ & $x$ & $x$ & $x$ & $x$ & $x$ \\
\hline 7. & 比如 & biru & $\checkmark$ & $x$ & $x$ & $x$ & $x$ & $x$ & $x$ & $\checkmark$ & $x$ & $x$ & $x$ & $\checkmark$ & $\checkmark$ \\
\hline 8. & 但 & dan & $x$ & $x$ & $x$ & $x$ & $x$ & $x$ & $x$ & $x$ & $\checkmark$ & $x$ & $x$ & $x$ & $x$ \\
\hline
\end{tabular}

$\underline{\text { Keterangan: }}$ tanda $(\checkmark)$ berarti ditemukan pemakaian kata pada responden tersebut.

Analisis tabel 7: Kelompok Konjungsi.

Pada tabel 1 diketahui ada 12 (dua belas) buah konjungsi, dan tampak di tabel 7 beberapa kata berikut ini telah dipilih dan digunakan oleh para responden, yaitu:

- Konjungsi 跟 (gen) yang artinya “dengan”, digunakan oleh responden 11;

- Konjungsi 因为 (yinwei) yang artinya "karena", digunakan oleh responden 4,6,9 dan 13;
- Konjungsi 和 (he) yang artinya "dan", digunakan oleh responden 2;

- Konjungsi 比如说 (birushuo) yang arinya "andai kata", digunakan oleh responden 3,6 dan 12;

- Konjungsi 连..., 都... (lian..., dou...) yang artinya "....pun.... / ....juga....", digunakan oleh responden 6 ; 
- Konjungsi ... 的时候 (...de shihou) yang artinya "pada saat....", digunakan oleh responden 3 dan 8;

- Konjungsi 比如 (biru) yang artinya "misalnya", digunakan oleh responden $1,8,12$ dan 13 ;
- Konjungsi 但 (dan) yang artinya "tetapi”, digunakan oleh responden 9.

Tabel 8. Daftar Ajektiva yang Digunakan oleh Responden 1-13.

\begin{tabular}{|c|c|c|c|c|c|c|c|c|c|c|c|c|c|c|c|}
\hline \multicolumn{3}{|c|}{ Kata-kata yang digunakan } & $R I$ & $R 2$ & $R 3$ & $R 4$ & $R 5$ & $R 6$ & $R 7$ & $R 8$ & $R 9$ & $R 10$ & RII & $R I 2$ & $R 13$ \\
\hline 1. & 一样 & yiyang & $\checkmark$ & $x$ & $x$ & $x$ & $x$ & $\checkmark$ & $\checkmark$ & $\checkmark$ & $x$ & $x$ & $\checkmark$ & $x$ & $x$ \\
\hline 2. & 好 & hao & $x$ & $x$ & $x$ & $x$ & $x$ & $\checkmark$ & $x$ & $x$ & $x$ & $x$ & $x$ & $x$ & $x$ \\
\hline 3. & 安然 & anran & $x$ & $x$ & $x$ & $x$ & $x$ & $x$ & $x$ & $x$ & $x$ & $x$ & $\checkmark$ & $\checkmark$ & $x$ \\
\hline
\end{tabular}

Keterangan: tanda $(\checkmark)$ berarti ditemukan pemakaian kata pada responden tersebut.

Analisis tabel 8: Kelompok Ajektiva.

Pada tabel 1 diketahui ada 15 (lima belas) buah ajektiva, dan dalam tabel 8 tampak beberapa kata telah dipilih dan digunakan oleh para responden, yaitu:

- Ajektiva 一 样 (yiyang) yang berarti "sama", digunakan oleh responden 1,6,7,8 dan 11;

- Ajektiva 好 (hao) yang berarti "baik", digunakan oleh responden 6;

- Ajektiva 安然 (anran) yang berarti "tentram", digunakan oleh responden 11 dan 12.

\section{SIMPULAN}

Penelitian ini menghasilkan dua buah simpulan yang mendukung pemanfaatan media audiovisual sebagai alat bantu untuk menolong para responden dalam memaparkan argumentasi mereka sesuai dengan tema yang diangkat. Hal ini dapat dilihat dari:

1. Pertama, bahwa para responden dapat memakai kata-kata yang diperoleh dari materi audiovisual. Kata-kata tersebut terdiri dari:

a. Preposisi 在 (zai) dan 从 (cong);

b. Nomina 台湾 (Taiwan), 中 国 (Zhongguo), 文化 (wenhua), 人 (ren), 两岸 (liang'an), 古代 (gudai), 书 (shu), 生活 (shenghuo), 整体 (zhengti), 神 (shen), 鬼 (gui), 点 (dian), 礼仪 (liyi), 影响 (yingxiang), 现在 (xianzai), 价值 (jiazhi), 现代人 (xiandai ren);

c. Pronomina 每 (mei), 自己 (ziji), 我们 (women), 我 (wo), 这样 (zheyang), 他 们 (tamen), 这 (zhe), 她 (ta), 那么 (name); d. Adverbia 其实 (qishi), 完全 (wanquan), 都 (dou), 在一起 (zaiyiqi), 很 (hen), 尤 其是 (youqi shi), 更 (geng);

e. Verba 感觉 (ganjue), 说 (shuo), 有 (you), 会 (hui), 想 (xiang), 用 (yong), 包括 (baokuo), 保持 (baochi), 能 (neng), 可以(keyi), 看到 (kan dao), 影 响 (yingxiang), 具有 (juyou), 带 (dai), 知道 (zhidao), 发扬 (fayang), 忽略 (hulue), 边陲化 (bianchuihua), 消失 (xiaoshi);

f. Konjungsi 跟 (gen), 因为 (yinwei), 和 (he), 比如说 (birushuo), 连 ...., 都... (lian...,dou...), ...的时候 (...de shihou), 比如 (biru), 但 (dan);

g. Ajektiva一样 (yiyang), 好(hao), 安然 (anran).

2. Kedua, bahwa pemaparan argumentasi dari para responden menunjukkan adanya keselarasan dengan tema diskusi yang diangkat di dalam materi audiovisual. Hal ini terkait dengan simpulan pertama, dimana para responden telah menggunakan kosakata yang diambil dari materi audiovisual, serta merangkaikan katakata tersebut menjadi sebuah pemaparan argumentasi yang bertemakan nilai-nilai budaya di antara dua tepian (RRT dan Taiwan).

\section{DAFTAR PUSTAKA}

Hesheng, Z. (2006). Duiwai Hanyu Ketang Jiaoxue Jiqiao Yanjiu. Shangwu Yinshuguan Chuban.

Huiyuan, Y. (2005). Hanyu Tingli Shuohua 
PENGARUH MEDIA AUDIOVISUAL TERHADAP KEMAMPUAN BERARGUMENTASI ...

Jiaoxuefa. In 2005 (4th ed.). Yuyan Daxue Chubanshe.

Jianxiong, T. (2008). Xiandai Hanyu (2nd ed.). Hebei Renmin Chubanshe.

Kridalaksana, H. (2005). Kelas Kata dalam Bahasa Indonesia (4th ed.). PT Gramedia Pustaka Utama.
Tarigan, H. G. (2008). Menyimak Sebagai Suatu Keterampilan Berbahasa. Angkasa.

Thoir, N., \& Danawaty, N. M. (1984). Tatabahasa Jilid III: Sintaksis Bahasa Indonesia. SLUA Saraswati. 